\title{
Pemanfaatan Minyak Kelapa (Cocos nucifera L.) untuk Memancing Kehadiran Semut (Hymenoptera: Formicidae)
}

\author{
Ari Sugiarto \\ Email: sugiartoari13@gmail.com
}

\begin{abstract}
Abstrak
Semut memiliki ketertarikan terhadap karbohidrat berdasarkan penelitian-penelitian yang sudah dilakukan orang. Berdasarkan penelitian lainnya menunjukkan dalam residu minyak kelapa masih terdapat kandungan karbohidrat yang cukup tinggi. Perlu dilakukannya penelitian mengenai pemanfaatan minyak kelapa untuk memancing kehadiran semut. Hasil dari penelitian ini dapat menunjukkan potensi minyak kelapa untuk memancing kehadiran semut tertentu. Pengujian minyak kelapa untuk memancing kehadiran semut ini dilakukan pada lokasi serasah, semak, dan tanah lapang di perkebunan Desa Serdang Menang. Pemilihan lokasi pengujian pada serasah, semak, dan tanah lapang memungkinkan adanya perbedaan spesies semut pada lokasi tersebut. Metode yang digunakan yaitu dengan mengoleskan minyak kelapa pada kapas dan kemudian diletakkan pada lokasi serasah, semak, dan tanah lapang. Hasil penelitian didapatkan spesies semut Dolichoderus sp. dan Tapinoma sp. tertarik dengan minyak kelapa yang diletakkan pada lokasi serasah, semak, dan tanah lapang. Diperkirakan spesies semut yang ada pada lokasi serasah, semak, dan tanah lapang tidak hanya Dolichoderus sp. dan Tapinoma sp. Minyak kelapa dapat memancing kehadiran Dolichoderus sp. dan Tapinoma sp. pada lokasi serasah, semak, dan tanah lapang diperkebunan Desa Serdang Menang, hal ini dapat menunjukkan adanya potensi minyak kelapa sebagai atraktan untuk spesies semut Dolichoderus sp. dan Tapinoma sp.
\end{abstract}

Kata kunci: Dolichoderus sp., Minyak kelapa, Semut, Tapinoma sp.

\section{Pendahuluan}

Kelapa (Cocos nucifera L.) merupakan tanaman asli dari Brunei Darussalam, Filipina, Indonesia, Kamboja, Laos, Malaysia, Myanmar, Singapura, Thailand, dan Vietnam. Kelapa dapat tumbuh dengan subur pada daerah pesisir yang beriklim tropis maupun subtropis dan juga dapat tumbuh jauh dari daerah pesisir. Salah satu pemanfaatan kelapa yaitu dimanfaatkan buahnya untuk dijadikan minyak. Residu minyak kelapa mengandung $20 \%$ protein, $45 \%$ karbohidrat, $11 \%$ serat, lemak, mineral dan air (Orwa et al., 2009).

Karbohidarat memiliki kaitan terhadap koloni semut seperti penelitian yang dilakukan Dussutour dan Simpson (2008) yang menunjukkan bahwa pengaturan konsentrasi larutan gula berpengaruh terhadap koloni semut. Menurut Detrain dan Jacques (2014), pemberian makan sukrosa lebih cepat direspon semut dibadingkan respon pemberian makan melezitose, fruktosa, dan glukosa.

Perlu dilakukan penelitian mengenai manfaat minyak kelapa untuk memancing kehadiran semut. Hasil dari penilitan ini juga dapat melihat potensi minyak kelapa sebagai atraktan terhadap spesies semut tertentu.

\section{Metode Penelitian}

Ekstraksi minyak kelapa dilakukan dengan metode ekstraksi panas (Mikołajczak, 2017). Kriteria kelapa yang diekstraksi yaitu telah memiliki tunas, yang menunjukkan banyak minyak yang terkandung pada bagian endosperm. Bagian endosperm ini dihaluskan, kemudian ditambahkan air secukupnya untuk mendapatkan pati. Endosperm yang telah dihaluskan dan telah ditambahkan air kemudian diperas untuk mendapatkan air 
patinya. Air pati yang telah didapat kemudian dipanaskan sampai terbentuk minyak kelapa.

Minyak kelapa yang telah didapat dari proses ekstraksi digunakan untuk memancing kehadiran semut. Minyak kelapa dioleskan pada kapas, kemudian kapas yang sudah sudah dioleskan minyak kelapa diletakkan pada lokasi serasah, semak, dan tanah lapang. Pemilihan lokasi ini melihat hasil penelitian Haneda dan Nisfi (2015) yang menunjukkan adanya perbedaan jumlah spesies semut pada ekosistem yang berbeda. Pemilihan lokasi pengujian minyak kelapa untuk memancing kehadiran semut ini dilakukan di Perkebunan Desa Serdang Menang, Kecamatan Sirah Pulau Padang, Kabupaten Ogan Komering Ilir. Lama waktu pengujian yaitu 1 jam untuk memancing kehadiran semut pada ruang lingkup yang besar, hal in mempertimbangkan dari hasil penelitian Detrain dan Jacques (2014), dalam waktu 10 detik semut sudah dapat menemukan sumber gula pada ruang lingkup yang kecil.

Identifikasi spesies semut yang didapatkan, dilakukan dengan mencocokan spesies semut yang sudah teridentifikasi spesiesnya.

\section{Hasil dan Pembahasan}

Berdasarkan penelitian yang dilakukan didapatkan hasil yaitu:

Tabel 1. Spesies semut yang tertarik dengan minyak kelapa yang diletakkan pada serasah, semak, dan tanah lapang

\begin{tabular}{ll}
\hline Lokasi & Spesies \\
\hline Serasah & $\begin{array}{l}\text { Dolichoderus } \mathrm{sp} . \\
\text { Tapinoma } \mathrm{sp} .\end{array}$ \\
\hline Semak & $\begin{array}{l}\text { Dolichoderus } \mathrm{sp} . \\
\text { Tapinoma } \mathrm{sp} .\end{array}$ \\
\hline Tanah lapang & Tapinoma $\mathrm{sp}$. \\
\hline
\end{tabular}

Ditemukan dua spesies semut yaitu Dolichoderus sp. dan Tapinoma sp. yang tertarik dengan minyak kelapa pada semua lokasi. Spesies semut yang tertarik minyak kelapa yang diletakkan pada serasah dan semak yaitu Dolichoderus sp. dan Tapinoma sp., sedangkan spesies semut yang tertaik dengan minyak kelapa pada lokasi tanah lapang yaitu Tapinoma sp.

Spesies yang ada pada lokasi serasah, semak, dan tanah lapang di perkebunan Desa Serdang Menang tentunya lebih banyak lagi dari spesies semut yang tertarik dengan minyak kelapa. Hal ini dapat dinilai bahwa pada inventarisasi semut di wilayah lain seperti yang dilakukan Lutinski et al. (2017), menemukan 52 spesies semut di hutan Atlantik, Brazil Selatan. Ranny et al. (2015), menemukan 12 spesies semut di perkebunan buah naga Lubuk Minturun. Franco dan Rodrigo (2018), menemukan 163 spesies di padang rumput Paraná. Menurut Fisher (2005), efek dari habitat dapat mempengaruhi efisiensi metode yang dipakai untuk menangkap semut.

Dolichoderus sp. dan Tapinoma sp. memungkinkan tertarik dengan minyak kelapa. Beberapa spesies semut tertarik dengan gula sperti penelitian yang dilakukan oleh Detrain dan Jacques (2014), menunjukkan bahwa Lasius niger memiliki ketertarikan pada gula (sukrosa). Dussutour dan Simpson (2008), terdapat pengaruh gula (sukrosa) terhadap pertumbuhan koloni Rhytidoponera metallica.

Kandungan yang terdapat pada residu minyak kelapa yaitu $20 \%$ protein, $45 \%$ karbohidrat, $11 \%$ serat, lemak, mineral dan air (Orwa et al., 2009). Menurut Mikołajczak (2017), minyak kelapa mengandung asam lemak (asam kaproat, asam kaprilat, asam kaprat, asam laurat, asam miristat, asam palmitat, asam stearat, asam oleat, asam linoleat, dan asam linolenat), sterol (campesterol, stigmasterol, dan $\beta$-sitosterol), tokol (tokoferol $(\alpha-\mathrm{T}, \quad \beta-\mathrm{T}, \quad \gamma-\mathrm{T}, \Delta-\mathrm{T})$ dan tokotrienol $(\alpha-\mathrm{T} 3, \beta-\mathrm{T} 3, \gamma-\mathrm{T} 3, \Delta-\mathrm{T} 3))$, dan asam fenolik (asam protocatechuic, asam vanilat, asam caffeic, asam syringic, asam ferulic, asam p-coumaric, asam galat, dan asam p-hydroxybenzoic). 
Perlu dilakukan penelitian lainnya untuk mengetahui senyawa spesifik yang menyebabkan spesies semut Dolichoderus sp. dan Tapinoma sp. tertarik pada minyak kelapa.

\section{Kesimpulan}

Minyak kelapa dapat memancing kehadiran Dolichoderus sp. dan Tapinoma sp. pada lokasi serasah, semak, dan tanah lapang diperkebunan Desa Serdang Menang, hal ini dapat menunjukkan adanya potensi minyak kelapa sebagai atraktan untuk spesies semut Dolichoderus sp. dan Tapinoma sp.

\section{Daftar Pustaka}

Detrain, C dan Jacques, P. 2014. Sensitivity and Feeding Efciency of The Black Garden Ant Lasius niger to Sugar Resources. Journal of Insect Physiology. 64(1): 74-80.

Dussutour, A dan S.J. Simpson. 2008. Carbohydrate Regulation in Relation to Colony Growth in Ants. The Journal of Experimental Biology. 211(1): 2224-2232.

Fisher, B.L. 2005. A Model for a Global Inventory of Ants: A Case Study in Madagascar. Proceedings of The California Academy of Sciences. 56(8): 86-97.

Franco, W dan Rodrigo, M.F. 2018. First Standardized Inventory of Ants (Hymenoptera: Formicidae) in the natural grasslands of Paraná: New records for Southern Brazil. Papéis Avulsos de Zoologia. 58(12): 1-8.

Haneda, N.F dan Nisfi, Y. 2015. Komunitas Semut (Hymenoptera: Formicidae) pada Empat Tipe Ekosistem yang Berbeda di Desa Bungku Provinsi Jambi. Jurnal Silvikultur Tropika. 6(3): 203-209.
Lutinski, J., Cladis, J.L., Carin, G., Maria, A.B., dan Flavio, R.M.G. 2017. Richness and Structure of Ant Assemblies (Hymenoptera: Formicidae) in Atlantic Forest in Southern Brazil. Anais da Academia Brasileira de Ciências. 89(4): 2719-2729.

Mikołajczak, N. 2017. Coconut Oil in Human Diet - Nutrition Value and Potential Health Benefits. Journal of Education, Health and Sport. 7(9): 307-319.

Orwa C, A Mutua, Kindt R , Jamnadass R, S Anthony. 2009 Agroforestree Database:a tree reference and selection guide version 4.0. (Online).http://www.worldagrofor estry.org/sites/treedbs/treedatabas es.asp. Diakses pada tanggal 1 November 2018.

Ranny., Henny, H., dan Dahelmi. 2015. Inventarisasi Semut yang Ditemukan pada Perkebunan Buah Naga Lubuk Minturun, Kota Padang dan Ketaping, Kabupaten Padang Pariaman, Sumatera Barat. Jurnal Biologi Universitas Andalas. 4(1): 57-64. 